\title{
PHENOLOGY AND REPRODUCTIVE TRAITS OF PEACHES AND NECTARINES IN CENTRAL-EAST ARGENTINA
}

\author{
Norberto Francisco Gariglio*; Marisa Mendow; Marcela Emilce Weber; María Alejandra \\ Favaro; Diego Esteban González-Rossia; Rubén Andrés Pilatti \\ Universidad Nacional del Litoral/Facultad de Ciencias Agrarias, Kreder 2805 (3080) Esperanza, Santa Fe - \\ Argentina. \\ *Corresponding author <ngarigli@fca.unl.edu.ar>
}

\begin{abstract}
In Santa Fe, the central-east area of Argentina, the expansion of fruit tree crops requires the introduction and evaluation of low chilling varieties. The aims of this study was to characterize the phenological behaviour and the reproductive traits of peach (Prunus persica L. Batsch) and nectarine varieties with chilling requirements ranging from 150 to 650 chilling hours $(\mathrm{CH})$. Low chilling varieties $(\leq 450 \mathrm{CH})$ had higher flower density $\left(22.0-56.5\right.$ flowers $\left.\mathrm{m}^{-1}\right)$, fruit set (26.0-56.7\%), fruit yield (9.3-36.6 $\mathrm{kg}$ per plant), and low coefficient of fruit yield variability than varieties with a higher chilling requirement $(>500 \mathrm{CH})$. The phenology of high chilling requirement varieties had the advantage that blooming and fruit set happened after the period of late frost occurrence. However, they did not satisfy their chilling requirement, showing an inadequate vegetative and reproductive behaviour. Low chilling varieties began to sprout during July, and the period of full bloom occurred from July $14^{\text {th }}$ to August $4^{\text {th }}$. Fruit harvest was initiated on October $19^{\text {th }}$ with the cv. 'Flordastar' and it extended for 58 days. However, on low chilling varieties the harvest time was reduced in ten days. Flower density, fruit set and fruit yield showed a negative relationship with the chilling requirement of the variety.

Key words: $\mathrm{BBCH}$ scale, stone fruits, flower intensity, fruit yield, low chilling requirement
\end{abstract}

\section{FENOLOGIA E COMPORTAMENTO REPRODUTIVO DE PÊSSEGO NO CENTRO-LESTE DAARGENTINA}

\begin{abstract}
RESUMO: Na região centro-leste do estado de Santa Fé, Argentina, para a expansão dos frutais é preciso introduzir variedades de baixo requerimento de frio. $\mathrm{O}$ objetivo deste estudo foi caracterizar o comportamento durante as fases de crescimento e frutificação de variedades de pêssego (Prunus persica L. Batsch) e nectarina com requerimentos de frio que variam entre 150-650 horas de frio $(\mathrm{CH})$. As variedades de pêssego de baixa necessidade de frio $(\leq 450 \mathrm{CH})$ mostraram maior densidade de flores (22.0-56.5 flores $\left.\mathrm{m}^{-1}\right)$, de estabelecimento de frutos (26.0-56.7\%), e rendimento de fruta (9.3-36.6 $\mathrm{kg}$ por planta) comparado com variedades de pêssego com necessidade de frio maior ( $>500 \mathrm{CH})$. As variedades de maior necessidade de frio tiveram a vantagem da floração, e o estabelecimento dos frutos aconteceu depois do período de risco de geadas. Porém, essas variedades não têm satisfeita sua necessidade de frio, apresentando comportamento vegetativo e reprodutivo inadequado. As variedades de baixa necessidade de frio brotaram entre 4 a 31 de julho e o período de plena floração aconteceu entre 14 de julho a 4 de agosto. A colheita de fruta começou em 19 de outubro com o cv. 'Flordastar', e sua duração foi de 58 dias. Para as variedades de baixa necessidade de frio o período de colheita foi dez dias mais curto.

Palavras-chave: BBCH escala, frutas de caroço, intensidade de floração, rendimento de fruta, baixa exigência de frio
\end{abstract}

\section{INTRODUCTION}

Peach (Prunus persica L. Batsch) trees are grown on almost 30,000 hectares in Argentina. They are mainly placed in the provinces of Mendoza and Buenos Aires (INDEC, 2002). Both of them are characterized by the use of medium and high chilling varieties (Carrá de Toloza, 2001; Valentini, 2002). The province of
Santa Fe contributes with a small proportion of the whole fruit production of Argentina (INDEC, 2002); however, there is an important encouragement for the expansion of fruit production, due to the propitious ecological conditions, the abundant availability of high quality water, and the possibility of obtaining early peach production. Besides this, the expansion of fruit tree crops in the central-east area of the Santa Fe prov- 
ince requires the introduction and evaluation of low chilling fruit trees; average chilling accumulation hardly reached 300 chilling hours $(\mathrm{CH})$ (Dovis et al., 2005), which is lower than half in comparison with the traditional peach production areas of Argentina.

The quantity of chilling hours accumulated in a certain area is a very important ecological requirement for the adaptation of temperate fruit trees (Faust, 1989; Squire, 1990; Valentini, 1994; Gil Albert, 1996; Lang, 1996; Erez et al., 1998), because of the influence of chilling on the release of dormancy (Faust et al., 1997; Dennis Jr., 2002). Up to date, there is no validated method for the characterization of the number of $\mathrm{CH}$ for the central-east region of the province of Santa Fe, and therefore it is important to test the agronomic behavior on the field of a wide range chilling requirements varieties, mainly of low chilling cultivars, which are not widely grown and known in Argentina (Ayalón Luaces et al., 2004). The objective of this research was to characterize the phenological behaviour and the reproductive traits of different peach and nectarine varieties with chilling requirements ranging from 150 to $650 \mathrm{CH}$, grown under the weather conditions of the central-east region of the province of Santa Fe, a non traditional peach production area of Argentina.

\section{MATERIALAND METHODS}

The evaluations were carried out in Esperanza $\left(31^{\circ} 26^{\prime} \mathrm{S} ; 60^{\circ} 56^{\prime} \mathrm{W} ; 40 \mathrm{~m}\right.$ above sea level), in the province of Santa Fe, Argentina. The evolution of chilling hour accumulation below $7.2^{\circ} \mathrm{C}$ during winter and heat unit summation above the $4.5^{\circ} \mathrm{C}$ (Citadin et al., 2001) base temperature from bloom to leaf drop are shown in Figure 1 with the objective of summarizing temperature conditions in the study area.

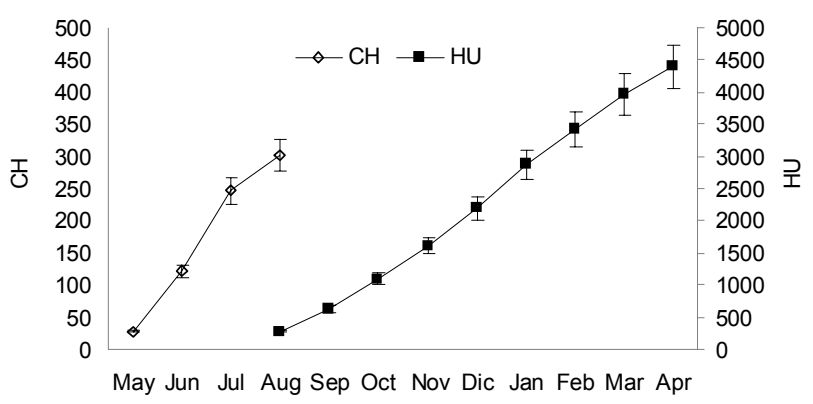

Figure 1 - Chilling hour $(\mathrm{CH})$ accumulation during winter (below $7.2^{\circ} \mathrm{C}$ ), and heat unit (HU) summation (above $4.5^{\circ} \mathrm{C}$ base temperature) during the vegetative growth period, for peach cultivation at the central-east area of Santa Fe, Argentina. Data are the means of six years (20022007). $\mathrm{CH}$ and $\mathrm{HU}$ standard error for each sample is represented by the vertical bar.
Four year old peach trees (Prunus persica L. Batsch) were used, planted $5 \times 5 \mathrm{~m}$ apart on a siltloamy soil and grafted onto 'Cuaresmillo' seedling rootstocks, with complementary drip irrigation and trained to the standard open vase system. Fertilization, pest management and pruning were made in accordance to normal commercial practices.

Thirteen peach and two nectarine (n) cultivars with different chilling requirements were evaluated: 'Spring Lady', (650 chilling hour $(\mathrm{CH})$ requirement), 'Maycrest' (600 CH), 'June Gold' $(520 \mathrm{CH})$, 'Flavorcrest' (509 CH), 'Flordaking' $(450 \mathrm{CH})$, 'Hermosillo' (350 CH), 'Don Agustín' (Fla. 81-12; 300 CH), 'San Pedro 1633' (297 CH), 'Earlygrande' (260 $\mathrm{CH})$, 'Tropic Snow' (250 CH), 'Flordastar' $(250 \mathrm{CH})$, 'Flordaprince' (150 CH) (Valentini, 2002), Fla.91-8c $(100 \mathrm{CH}$, according to its behaviour in Santa Fe, Argentina), 'Lara' (n) (350 CH), and 'Carolina' (n) (325 $\mathrm{CH})$ (INIA Salto Grande, 2003).

Trees were chosen by their uniformity in size and vigour. During the winter, ten homogeneous current season shoots per plant were randomly selected 1.8 $\mathrm{m}$ above the ground level and their lengths were also measured. The phenological phases of leafing, beginning of flowering, full flowering, and fruit set, were weekly observed from the end of the winter rest to the end of harvest time at the selected twigs by using the "Biologische Bundesanstalt, Bundessortenamt" and Chemical industry (BBCH) scale for stone fruit (Meier et al., 1994). Furthermore, the number of vegetative shoots, flowers and fruits were weekly measured at the selected twigs from the release of dormancy to the stage of pit hardening. Data were expressed as the mean number of flowers per metre of shoot length, percentage of vegetative bud break, and percentage of fruit set. The percentage of fruit set was calculated as the ratio between the number of fruit at pit hardening and the maximum number of flowers measured at full bloom in each selected twig. The experiment was conducted over a six year (20022007) period.

A randomised complete-block design with one-tree plots and eight replications per cultivar was used. Analysis of regression and variance were performed on the data, and means were compared by Tukey's test $(p \leq 0.01)$.

\section{RESULTS}

\section{Phenology}

Peach and nectarine varieties with a chilling requirement lower than $450 \mathrm{CH}$, start leafing during July, with $70 \%$ of the varieties sprouting during 10 days from July 11 . High chilling requirement variet- 
ies $(>500 \mathrm{CH})$ showed sprouting during the second and third weeks of September, at least 67 days later than 'Fla. 91-8c', the most precocious variety (Table 1). With the exception of 'Maycrest' and 'Spring Lady', all cultivars showed percentage of budbreak higher than $60 \%$, despite of their chilling requirement (Table 1).

The period of full bloom occurred from July $14^{\text {th }}$ to August $4^{\text {th }}$ for low chilling varieties $(\leq 450 \mathrm{CH})$ and from September $10^{\text {th }}$ to $20^{\text {th }}$ for high chilling varieties (Table 2). Fruit set was observed at the beginning of August for 'Fla. 91-8c' (Table 2); however, the majority of low chilling varieties $(\leq 450 \mathrm{HF})$ showed the phenological stage of fruit set at least one week later, from August $10^{\text {th }}$ to $23^{\text {rd }}$ (Table 2). High chilling requirement varieties $(\geq 500 \mathrm{CH})$ reached fruit set by the end of September, which was 36 and 55 days later than 'Flordaking' and 'Fla. 91-8c', respectively (Table 2).

Harvest was initiated on October $19^{\text {th }}$ with the cv. 'Flordastar' (Table 2) and it extended over 58 days, 'Flavorcrest' being the last harvested variety. The period of harvest was reduced by 10 days when only low chilling varieties $(\leq 450 \mathrm{HF})$ were taken into account, with 'Hermosillo' as the latest harvest variety.

\section{Reproductive traits}

'Tropic Snow', and the nectarines 'Lara' and
'Carolina', presented the highest flower density (FD) (Table 3), followed by 'Hermosillo' and 'Flordastar'. 'Flavorcrest' had the lowest FD, which was 76\% lower than 'Carolina'. The other peach varieties were not different, and the FD ranged from 22.0 to 29.6 flower $\mathrm{m}^{-1}$ (Table 3).

'Flordastar' and 'Flordaprince' had the higher values of fruit set (Table 3 ). With the exception to the nectarine 'Lara', low chilling varieties ( $\leq$ $450 \mathrm{CH}$ ) had over $26 \%$ fruit set, which was at least $65 \%$ higher than high chilling varieties $(\geq 500$ $\mathrm{CH})$.

Fruit size varied among genotypes (Table 3). 'Hermosillo' had the largest fruit size, but did not differ from 'June Gold'. Other five varieties had a fruit size of over $100 \mathrm{~g}_{\text {fruit }}{ }^{-1}$ ('Earlygrande', 'Tropic Snow', 'Flordaking', 'San Pedro 1633', and 'Don Agustín'). 'Flavorcrest' did not develop normal fruits; they were small and with high percentage of aborted embryos.

'Hermosillo' and 'Tropic Snow' had the highest fruit yield and the lowest coefficients of variability during the six year period (Table 4). The other low chilling varieties $(\leq 450 \mathrm{CH})$ had lower fruit yield than 'Hermosillo' and 'Tropic Snow'. The nectarines presented the lowest fruit yield among low chilling varieties. Fruit yield of high chilling requirement varieties

Table 1 - Time of leafing and percentage of vegetative bud-break for peach and nectarine (n) varieties grown in central-east Santa Fe, Argentina. Data are the means of six year (2002-2007) period.

\begin{tabular}{lccc}
\hline Cultivar & $\mathrm{CH}^{1}$ & $\begin{array}{c}\text { First leaves } \\
10^{2}\end{array}$ & $\mathrm{VB}^{3}$ \\
\hline & & & $\%$ \\
'Fla. 91-8c' & $100^{4}$ & $04 \mathrm{Jul} \pm 7$ & $70.4 \mathrm{~b}$ \\
\hline 'Flordaprince' & $150^{5}$ & $17 \mathrm{Jul} \pm 7$ & $76.9 \mathrm{a}$ \\
'Flordastar' & $250^{5}$ & $13 \mathrm{Jul} \pm 5$ & $70.2 \mathrm{~b}$ \\
'Tropic Snow' & $250^{5}$ & $21 \mathrm{Jul} \pm 6$ & $73.8 \mathrm{a}$ \\
'Earlygrande' & $260^{5}$ & $11 \mathrm{Jul} \pm 5$ & $74.8 \mathrm{a}$ \\
'San Pedro 1633' & $297^{5}$ & $19 \mathrm{Jul} \pm 5$ & $78.2 \mathrm{a}$ \\
'Don Agustín' (Fla. 81-12) & $300^{5}$ & $21 \mathrm{Jul} \pm 4$ & $68.4 \mathrm{~b}$ \\
'Carolina' (n) & $325^{6}$ & $29 \mathrm{Jul} \pm 5$ & $75.5 \mathrm{a}$ \\
'Hermosillo' & $350^{5}$ & $17 \mathrm{Jul} \pm 5$ & $69.8 \mathrm{~b}$ \\
'Lara' (n) & $350^{6}$ & $21 \mathrm{Jul} \pm 6$ & $68.7 \mathrm{~b}$ \\
'Flordaking' & $450^{5}$ & $31 \mathrm{Jul} \pm 4$ & $64.9 \mathrm{bc}$ \\
'June Gold' & $500^{5}$ & $14 \mathrm{Sep} \pm 9$ & $68.9 \mathrm{~b}$ \\
'Flavorcrest' & $509^{5}$ & $10 \mathrm{Sep} \pm 6$ & $68.5 \mathrm{~b}$ \\
'Maycrest' & $600^{5}$ & $9 \mathrm{Sep} \pm 4$ & $57.3 \mathrm{c}$ \\
'Spring Lady' & $650^{5}$ & $21 \mathrm{Sep} \pm 6$ & $50.4 \mathrm{~d}$ \\
\hline
\end{tabular}

Means within each column followed by the same letter are not different (Tukey's multiple comparison test, $p>0.01$ ). ${ }^{1}$ Chilling Hours $=$ chilling requirement of the cultivar; ${ }^{2}$ Phenological stage according to the $\mathrm{BBCH}$ scale for stone fruits (Meier et al., 1994); ${ }^{3} \mathrm{VB}=$ vegetative bud-break, expressed as the percentage of nodes that break dormancy; ${ }^{4}$ adjusted according to the behaviour in Santa Fe, Argentina; ${ }^{5}$ Valentini (2002); ${ }^{6}$ INIA Salto Grande (2003). 
Table 2 - Time of full blooming, fruit set and harvest for peach and nectarine (n) varieties grown in central-east Santa Fe, Argentina. Data are the means of six year (2002-2007) period.

\begin{tabular}{|c|c|c|c|c|}
\hline Cultivar & $\mathrm{CH}^{1}$ & $\begin{array}{l}\text { Full blooming } \\
65^{2}\end{array}$ & $\begin{array}{c}\text { Fruit set } \\
72^{2}\end{array}$ & Harvest \\
\hline 'Fla. 91-8c' & $100^{3}$ & $14 \mathrm{Jul} \pm 5$ & 05 Ago \pm 6 & 25 Oct \pm 3 \\
\hline 'Flordaprince' & $150^{4}$ & 01 Ago \pm 6 & 22 Ago \pm 3 & 03 Nov \pm 3 \\
\hline 'Flordastar' & $250^{4}$ & $26 \mathrm{Jul} \pm 6$ & 15 Ago \pm 5 & 19 Oct \pm 2 \\
\hline 'Tropic Snow' & $250^{4}$ & $27 \mathrm{Jul} \pm 7$ & 19 Ago \pm 4 & $19 \operatorname{Nov} \pm 2$ \\
\hline 'Earlygrande' & $260^{4}$ & $17 \mathrm{Jul} \pm 7$ & 12 Ago \pm 5 & 27 Oct \pm 1 \\
\hline 'San Pedro 1633' & $297^{4}$ & $15 \mathrm{Jul} \pm 6$ & 10 Ago \pm 5 & $5 \mathrm{Nov} \pm 2$ \\
\hline 'Don Agustín' (Fla. 81-12) & $300^{4}$ & $18 \mathrm{Jul} \pm 2$ & 16 Ago \pm 1 & $08 \mathrm{Nov} \pm 2$ \\
\hline 'Carolina' (n) & $325^{5}$ & 02 Ago \pm 3 & 20 Ago \pm 2 & $22 \operatorname{Nov} \pm 1$ \\
\hline 'Hermosillo' & $350^{4}$ & $24 \mathrm{Jul} \pm 7$ & 14 Ago \pm 4 & $26 \mathrm{Nov} \pm 2$ \\
\hline 'Lara' (n) & $350^{4}$ & $30 \mathrm{Jul} \pm 3$ & 20 Ago \pm 2 & $19 \operatorname{Nov} \pm 1$ \\
\hline 'Flordaking' & $450^{4}$ & 04 Ago \pm 5 & 23 Ago \pm 3 & 29 Oct \pm 3 \\
\hline 'June Gold' & $500^{4}$ & $10 \mathrm{Sep} \pm 3$ & $29 \mathrm{Sep} \pm 3$ & $23 \mathrm{Nov} \pm 2$ \\
\hline 'Flavorcrest' & $509^{4}$ & 19 Sep \pm 3 & 04 Oct \pm 3 & $06 \mathrm{Dic} \pm 3$ \\
\hline 'Maycrest' & $600^{4}$ & 15 Sep \pm 3 & 06 Oct \pm 5 & 17 Nov \pm 3 \\
\hline 'Spring Lady' & $650^{4}$ & 20 Sep \pm 3 & 08 Oct \pm 3 & $19 \mathrm{Nov} \pm 2$ \\
\hline
\end{tabular}

${ }^{1}$ Chilling Hours = chilling requirement of the cultivar; ${ }^{2}$ Phenological stage according to the BBCH scale for stone fruits (Meier et al., 1994); ${ }^{3}$ adjusted according to the behaviour in Santa Fe, Argentina; ${ }^{4}$ Valentini (2002); ${ }^{5}$ INIA Salto Grande (2003).

Table 3 - Flower density, percentage of fruit set, and fruit size for peach and nectarine (n) varieties grown in central-east Santa Fe, Argentina. Data are the means of six year (2002-2007) period.

\begin{tabular}{lccc}
\hline Cultivar & Flower density & Fruit set & Fruit size \\
\hline & flowers m-1 & $\%$ & $\mathrm{~g}$ \\
'Fla. 91-8c' & $22.0 \mathrm{de}$ & $30.1 \mathrm{c}$ & $86.4 \mathrm{~d}$ \\
'Flordaprince' & $27.8 \mathrm{~d}$ & $51.2 \mathrm{a}$ & $99.5 \mathrm{c}$ \\
'Flordastar' & $33.8 \mathrm{c}$ & $56.7 \mathrm{a}$ & $70.0 \mathrm{e}$ \\
'Tropic Snow' & $55.7 \mathrm{a}$ & $28.7 \mathrm{c}$ & $111.3 \mathrm{~b}$ \\
'Earlygrande' & $29.2 \mathrm{~d}$ & $39.7 \mathrm{~b}$ & $115.5 \mathrm{~b}$ \\
'San Pedro 1633' & $22.8 \mathrm{de}$ & $32.7 \mathrm{bc}$ & $110.4 \mathrm{~b}$ \\
'Don Agustín' (Fla. 81-12) & $29.6 \mathrm{~d}$ & $26.0 \mathrm{c}$ & $100.6 \mathrm{c}$ \\
'Carolina' (n) & $56.5 \mathrm{a}$ & $33.8 \mathrm{bc}$ & $68.8 \mathrm{e}$ \\
'Hermosillo' & $48.4 \mathrm{~b}$ & $30.0 \mathrm{c}$ & $126.2 \mathrm{a}$ \\
'Lara' (n) & $50.9 \mathrm{ab}$ & $8.6 \mathrm{e}$ & $85.6 \mathrm{~d}$ \\
'Flordaking' & $22.8 \mathrm{de}$ & $34.0 \mathrm{bc}$ & $110.7 \mathrm{~b}$ \\
'June Gold' & $24.4 \mathrm{de}$ & $15.7 \mathrm{~d}$ & $117.1 \mathrm{ab}$ \\
'Flavorcrest' & $13.3 \mathrm{e}$ & $6.3 \mathrm{e}$ & $28.7 \mathrm{f}$ \\
'Maycrest' & $23.2 \mathrm{de}$ & $13.8 \mathrm{~d}$ & $93.3 \mathrm{~d}$ \\
'Spring Lady' & $27.8 \mathrm{~d}$ & $6.7 \mathrm{e}$ & $72.8 \mathrm{de}$ \\
\hline
\end{tabular}

Means within each column followed by the same letter are not different (Tukey's multiple comparison test, $p>0.01$ ).

$(\geq 500 \mathrm{CH})$ was insignificant and had high variability among years (Table 4).

Flower density, fruit set and fruit yield of peach and nectarines grown at the central east area of the province of Santa Fe, presented a negative relationship with the chilling requirement of the genotype (Figure 2).

\section{DISCUSSION}

For peach-trees and other temperate fruit tree crops, the most critical phenological period affected by frost is from full bloom until fruit set (stage 71 and 72 in $\mathrm{BBCH}$ scale), causing high reduction of the annual fruit production (Fideghelli, 1987).

Sci. Agric. (Piracicaba, Braz.), v.66, n.6, p.757-763, November/December 2009 
Table 4 - Fruit yield and coefficient of variation for peach varieties grown in central-east Santa Fe, Argentina. Data represent the means of six year (2002-2007) period.

\begin{tabular}{llc}
\hline Cultivar & Fruit yield & $\begin{array}{c}\text { Coefficient of } \\
\text { variation }\end{array}$ \\
\hline 'Fla. 91-8c' & kg per plant & $\%$ \\
'Flordaprince' & $14.7 \mathrm{c}$ & 15 \\
'Flordastar' & $20.1 \mathrm{~b}$ & 16 \\
'Tropic Snow' & $14.0 \mathrm{c}$ & 14 \\
'Earlygrande' & $31.1 \mathrm{a}$ & 10 \\
'San Pedro 1633' & $20.8 \mathrm{~b}$ & 16 \\
'Don Agustín' (Fla. 81-12) & $12.6 \mathrm{c}$ & 13 \\
'Carolina' (n) & $9.3 \mathrm{~d}$ & 30 \\
'Hermosillo' & $36.6 \mathrm{a}$ & 18 \\
'Lara' (n) & $10.3 \mathrm{~d}$ & 9 \\
'Flordaking' & $24.0 \mathrm{~b}$ & 30 \\
'June Gold' & $4.7 \mathrm{e}$ & 20 \\
'Flavorcrest' & $0.4 \mathrm{f}$ & 85 \\
'Maycrest' & $2.9 \mathrm{f}$ & 88 \\
'Spring Lady' & $1.1 \mathrm{f}$ & 90 \\
\hline
\end{tabular}

Means within each column followed by the same letter are not different (Tukey's multiple comparison test, $p>0.01$ ).

September $5^{\text {th }}$ is the average date for last frost occurrence in the central area of the province of Santa Fe (Panigatti, 1980). In our experiment, blooming and fruit set in low chilling varieties $(\leq 450 \mathrm{CH})$ took place during the period of frequent late frost occurrence, whereas blooming and fruit set occurred after this period for varieties with a higher chilling requirement. Despite the fact that peach varieties with a higher chilling requirement appeared to be more adequate to avoid spring frosts, they showed a very low fruit yield with regard to the low chilling varieties. Chilling accumulation in the central-east area of the province of Santa Fe was around $300 \mathrm{CH}$ during the last eight years (Dovis et al., 2005). Consequently, only peach and nectarine varieties with low chilling requirement were able to cover their requirement for cold temperature. The above mentioned can explain the negative correlation between reproductive traits and chilling requirement observed for the peach and nectarine varieties grown at the central east area of the province of Santa $\mathrm{Fe}$ (Figure 2).

High chilling varieties reached blooming at least 36 days later than low chilling varieties. In the Mexican subtropics, peach accessions with late blooming showed low fruit yield due to relatively warm temperatures and dry winds during bloom-stage which reduced pollination and fertilization (Pérez, 2004). On the other
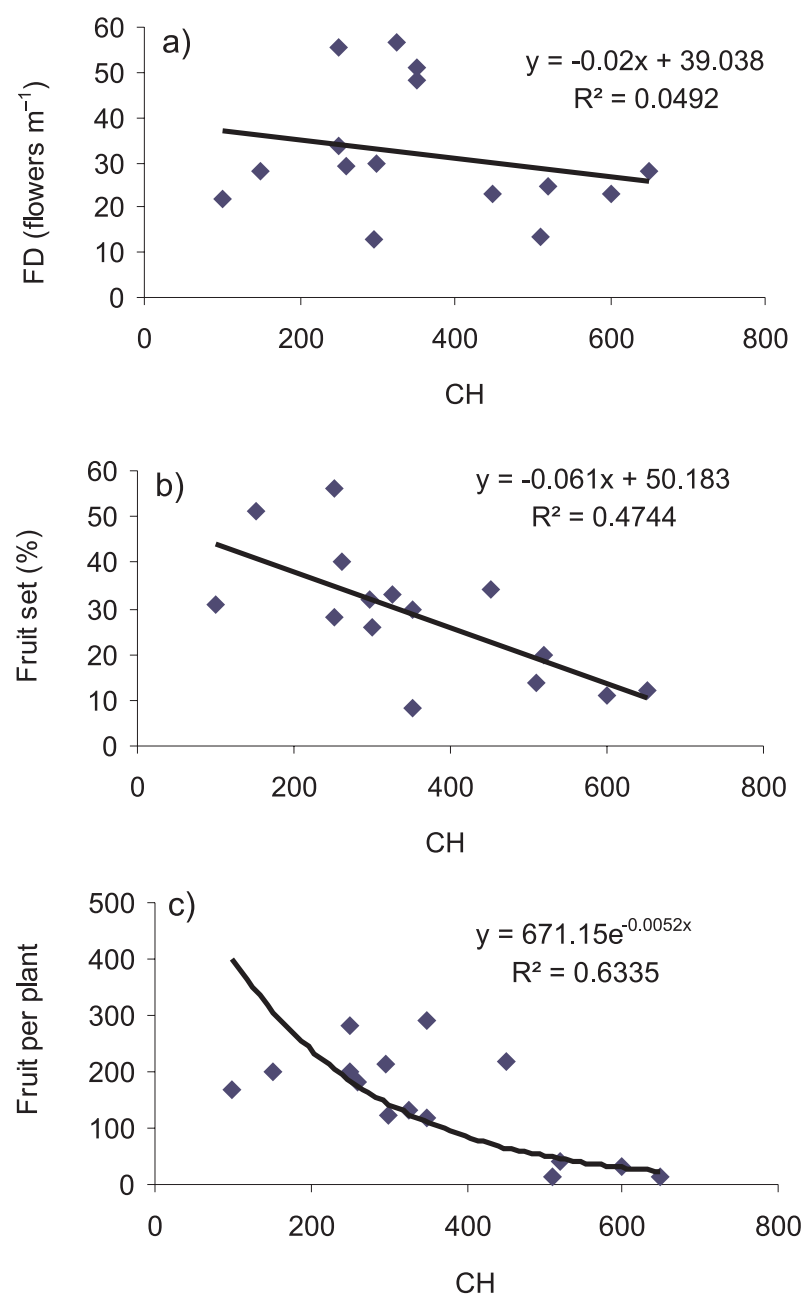

Figure 2 - Relationship between the intensity of flowering (FD) (a), the percentage of fruit set (b), and crop load (c), with the chilling requirement $(\mathrm{CH})$ of the cultivar, for peach varieties grown in central-east Santa Fe. Data are the means of six years (2002-2007).

hand, low chilling requirement varieties showed a better adaptation to the subtropical region of Mexico, in spite of the high risk of late winter frost. Low chilling peach varieties exhibited an extended bloom period and had a higher opportunity for fruit set after the occurrence of low temperature (Pérez, 2004). In the central area of the province of Santa Fe, the influence of the Paraná River tempers the intensity and duration of frosts; hence, spring frosts normally do not damage peach crops. In this study, only an intense frost at the end of August of 2004 (i.e. $-5^{\circ} \mathrm{C}$ ) caused frost damage in the last six-year period, producing fruit drops in all peach varieties, including the ones with a high chilling requirement (data not shown).

The south-east region of Brazil is also characterized by warm winters with great temperature fluctuations and frequent late frost occurrence (Citadin et al., 2001). Thus, the cultivars best adapted to southern 
Brazil have low chilling requirements (150-500 CH). However, once the chilling requirement is satisfied, they start blooming, so increasing the likelihood of damage by late winter frost (Citadin et al., 2001), the same occurs in the central-east area of the province of Santa Fe. Nevertheless, Citadin et al. (2001) observed that there are varieties of peach trees in Brazil, with high heat requirement for blooming once its chilling requirement has been satisfied, showing adaptation to colder regions $(600 \mathrm{CH})$ as well as to warmer regions $(200$ $\mathrm{CH}$ (Citadin et al., 2002). In this study, 'Flordaprince' had a similar behaviour; it was the variety with the lowest chilling requirement among the used ones, but it bloomed later, at least ten days after the majority of the low chilling varieties, and only four days before 'Flordaking'. Thus, 'Flordaprince' presented a phenological behaviour more similar to 'Flordaking', which had 3-fold higher chilling requirement (Table 2).

'Flordaking' was recommended for the central-east area of the province of Santa Fe (Gariglio et al., 2003), in spite of its chilling requirements $(450 \mathrm{CH})$, which are $50 \%$ higher than the average chilling accumulated in the area $(300 \mathrm{CH})$. In an experiment of artificial chilling using excised shoots, 'Flordaking' reached more than $50 \%$ of blooming and leafing in the range of 300 to 800 hours of chilling (Gariglio et al., 2006). This explains its broad adaptation to different areas, such as the north-east of the province of Buenos Aires (Valentini, 2002), the centre of the province of Cordoba (Italia, 1997), and the centre-east and northern area of the province of Santa Fe (Gariglio et al., 2003; Ortiz de Zárate \& Gariglio, 2004).

Flower density was lower in the experiment being considered and only five varieties reached a FD higher than 30 flower $\mathrm{m}^{-1}$. 'Springlady' peach cultivated under Mediterranean climatic conditions (González Rossia et al., 2007) showed a FD 2.2-fold higher (51.1 flowers $\mathrm{m}^{-1}$ ) than the recorded in our experiments. In the highlands of central Mexico, the average FD of 33 peach germplasm was 67 flower $\mathrm{m}^{-1}$ and only two peach varieties had less than 30 flowers $\mathrm{m}^{-1}$ (Pérez, 2004).

In the present study, the period of harvest lasted near two months, after October $19^{\text {th }}$. However, on low chilling requirement varieties the harvest time was reduced by ten days. The harvest was continuous, and the more extended period between the beginning of the harvest of two successive low chilling varieties was 11 days, from November $8^{\text {th }}$ (beginning of harvest of 'Don Agustín'), to November $19^{\text {th }}$ (beginning of harvest of 'Lara' and 'Tropic Snow'). Therefore, new low chilling peach and nectarine varieties should be evaluated to improve the continuity and distribution of harvest during this period of time. On the other hand, the use of more precocious varieties than 'Flordastar' does not seem to increase the whole harvest period because of the risk of late frost occurrence and the difficulty to obtain a proper fruit size. Another interesting alternative to extend the whole harvest period and fruit size and quality is the search for varieties with a later harvest period than 'Hermosillo'.

For the most precocious varieties, average harvesting date in the central-east area of the province of Santa Fe took place ten days before the average harvesting date of the most important peach production areas of the central region of Argentina (Valentini \& Arroyo, 2000). However, differences in harvesting dates between zones were reduced to six and two days for peach varieties harvested in mid and late November, respectively (Valentini \& Arroyo, 2000).

Fruit size was lower in this experiment than that observed in Valencia, Spain (Badenes et al., 1998), but differences in size varied among varieties. Fruit size was $15 \%$ lower for 'Tropic Snow', $45 \%$ lower for 'Flordaking' and 'Flordastar', and up to $82 \%$ lower for 'Flavorcrest', at the central-east area of the province of Santa Fe in relationship to Valencia (Spain).

In conclusion, low chilling peach and nectarine varieties $(\leq 450 \mathrm{CH})$ at the central-east area of the province of Santa Fe presented high flower density, fruit set, number of fruit per plant, and consequently, higher fruit yield with regard to peach varieties with higher chilling requirement $(>500 \mathrm{CH})$. The phenology of high chilling requirement varieties had the advantage that blooming and fruit set occurred after the period of risk of late frost occurrence, however, they did not satisfy their chilling requirement, showing an inadequate vegetative and reproductive behaviour.

\section{REFERENCES}

AYALÓN LUACES, P.; RODRÍGUEZ, V.A.; BERTUZZI, S.M. EI cultivo del manzano (Malus domestica Borkh.) en Corrientes: primer año de investigación. Corrientes: Universidad Nacional del Nordeste, 2004. p.1-4. (Comunicación científica y tecnológica A-029), Available at http:// www.unne.edu.ar/Web/cyt/com2004/5-Agrarias/A-029.pdf. Accessed 10 Nov. 2007.

BADENES, M.L.; MARTÍNEZ-CALVO, J.; LLACER, G. Estudio comparativo de la calidad de los frutos de 26 cultivares de melocotonero de origen norteamericano y dos variedadespoblación de origen español. Investigación Agraria: Producción y Protección Vegetal, v.13, p.57-70, 1998.

CARRÁ DE TOLOZA, M.S. Selección de variedades de duraznos de mesa y nectarinos promisorios y recomendados para su cultivo en la provincia de Mendoza. Horticultura Argentina, v.20, p.44, 2001.

CITADIN, I.; RASEIRA, M.C.B.; HERTER, F.G.; BAPTISTA DA SILVA, J. Heat requirement for blooming and leafing in peach. HortScience, v.36, p.305-307, 2001.

CITADIN, I.; RASEIRA, M.C.B.; HERTER, F.G.; POSSER SILVEIRA, C.A. Avaliação da necessidade de frio em pessegueiro. Revista Brasileira de Fruticultura, v.24, p.703-706, 2002. 
DENNIS JR., F.G. Dormancy: manifestations and causes. In: PESSARAKLI, M. (Ed.) Handbook of plant and crop physiology. 2 ed. New York: Marcel Dekker, 2002. Chapter 8, p.161-179.

DOVIS, V.; GARCÍA, M.S.; LEVA, P.E.; BOUZO, C.A.; GARIGLIO, N.F. Acumulación de frío en la zona centro-oeste de la provincia de Santa Fe. In: CONGRESO ARGENTINO DE HORTICULTURA, 28., La Plata, 2005. Libro de resúmenes. Buenos Aires. 2005. v.1, p.21.

EREZ, A.; FAUST, M.; LINE, M. Changes in water status in peach buds on induction, development and release from dormancy. Scientia Horticulturae, v.73, p.111-123, 1998.

FAUST, M. Physiology of temperate zone fruit trees. New York: John Wiley, 1989. 338p.

FAUST, M.; EREZ, A.; ROWLAND, L.J.; WANG, S.Y.; NORMAN, H.A. Bud dormancy in perennial fruit trees: physiological basis for dormancy induction, maintenance, and release. HortScience, v.32, p.623-629, 1997.

FIDEGHELLI, C. El melocotonero. Madrid: Mundi Prensa, 1987. $243 p$.

GARIGLIO, N.F.; ORTIZ DE ZÁRATE, V.G.; ZANUTTINI, A.M. Comportamiento reproductivo de 13 variedades de duraznero (Prunus persica L. Batsh) cultivados en la zona centro-este de la provincia de Santa Fe. Horticultura Argentina, v.20/22, p. 54,2003

GARIGLIO, N.F.; GONZÁLEZ-ROSSIA, D.E.; MENDOW, M.; REIG, C.; AGUSTÍ, M. Effect of artificial chilling on the depth of endodormancy and leaf and flower budbreak of peach and nectarine cultivars using excised shoots. Scientia Horticulturae, v.108, p.371-377, 2006.

GIL-ALBERT, F. Tratado de arboricultura frutal. I. Aspectos de la morfología y fisiología del árbol frutal. Madrid: Mundi-Prensa, 1996. 103p.

GONZÁLEZ ROSSIA, D.; REIG, C.; JUAN, M.; AGUSTÍ, M. Horticultural factors regulating effectiveness of $\mathrm{GA}_{3}$ inhibiting flowering in peaches and nectarines (Prunus persica L. Batsch). Scientia Horticulturae, v.111, p.352-357, 2007.

INDEC. Censo Nacional Agropecuario, 2002. Available at: http:// www.indec.mecon.gov.ar/agropecuario/cna_principal.asp. Accessed 15 Nov. 2005.

INIA SALTO GRANDE. Reunión anual de frutales de carozo. Salto Grande, 2003. 32p. Available at: http://www.inia.org.uy/ publicaciones/documentos/sa/ad/2003/ad_334.pdf. Accessed 20 Feb. 2006.
ITALIA, R.R. La fruticultura en el centro-norte de Córdoba. Buenos Aires: INTA, 1997. 45p. (Publicación Técnica, 31)..

LANG, G.A. Plant dormancy: physiology, biochemistry and molecular biology. Wallingford: CAB International, 1996. 386p.

MEIER, U.; GRAF, H.; HACK, H.; HESS, M.; KENNEL, W.; KLOSE, R.; MAPPES, D.; SEIPP, D.; STAUSS, R.; STREIF, J.; BOOM, T. van den. Phänologische entwick-lungsstadien des kernobstes (Malus domestica Borkh. und Pyrus communis L.), des steinobtes (Prunus-Arten), der johannisbeere (Ribes-Arten) und der erdbeere (Fragaria $x$ ananassa Dutch.). Nachrichtenbl Deutsch Pflazenschutzd, v.46, p.141-153, 1994.

ORTIZ DE ZÁRATE, V.G.; GARIGLIO, N.F. Comportamiento reproductivo de variedades precoces de duraznero (Prunus persica L. Batsch) en la zona centro-este de la Provincia de Santa Fe (Argentina). In: JORNADAS DE JOVENS PESQUISADORES DA AUGM, 12., Montevideo, 2004. Libro de resúmenes. Montevideo, 2004. v.1, p.61

PANIGATTI, J.L. Consideraciones sobre el clima del centrooeste de la Provincia de Santa Fe. Rafaela: INTA-Estación Experimental Regional Agropecuaria Rafaela. 1980. 26p. (Boletín interno de divulgación, 15).

PÉREZ, S. Yield stability of peach germplasm differing in dormancy and blooming season in the Mexican subtropics. Scientia Horticulturae, v.100, p.15-21, 2004.

SQUIRE, G.R. The physiology of tropical crop production. Wallingford: CAB International, 1990. 237p.

VALENTINI, G. Comportamiento de diferentes variedades en el área de influencia de la EEA San Pedro. In: CURSO FRUTALES DE CAROZO PARA ZONAS TEMPLADO HÚMEDAS, San Pedro, 1994. Libro de conferencias. San Pedro: INTAEstación Experimental Regional Agropecuaria San Pedro, 1994. $102 p$.

VALENTINI, G. Variedades de duraznero y nectarina para el NE de 1a Provincia de Buenos Aires, 2002. Available in http:// www.inta.gov.ar/sanpedro/info/doc/fru/gv_003.htm. Accessed 20 Mar. 2004.

VALENTINI, G.; ARROYO, L. Variedades y Portainjertos. In: JORNADA DE ACTUALIZACIÓN EN DIFERENTES ASPECTOS DEL CULTIVO DE DURAZNERO, San Pedro, 2000. Libro de conferencias. San Pedro: INTA-Estación Experimental Regional Agropecuaria San Pedro, 2000. p.2-8.

Received June 04, 2008

Accepted May 19, 2009 